\title{
Effect of acetylsalicylic acid on total myenteric neurons in mice experimentally infected with Trypanosoma cruzi
}

\author{
NOEMI D. DE SOUZA ${ }^{1}$, BRUNA S. BELIN ${ }^{1}$, CRISTINA L. MASSOCATTO ${ }^{2}$, SILVANA M. DE ARAÚJO ${ }^{3}$, \\ DÉBORA M.G. SANT'ANA ${ }^{4}$, EDUARDO J.A. ARAÚJO ${ }^{5}$, PHILENO P. \\ FILHO $^{6}$, OSCAR K. NIHEI ${ }^{1}$ and NEIDE M. MOREIRA ${ }^{1}$
}

\author{
${ }^{1}$ Grupo de Pesquisa em Saúde Coletiva em Enfermagem/GPSCE, Universidade Estadual do Oeste do Paraná/ \\ UNIOESTE, Avenida Tarquínio Joslin dos Santos, 1300, 85870-650 Foz do Iguaçu, PR, Brazil \\ ${ }^{2}$ Curso de Farmácia, Faculdade Integrado de Campo Mourão, \\ Rodovia BR 158, Km 207, 87300-970 Campo Mourão, PR, Brazil \\ ${ }^{3}$ Departamento de Ciências Básicas da Saúde, Universidade Estadual de Maringá/ \\ UEM, Avenida Colombo, 5790, Zona 07, 08020-900 Maringá, PR, Brazil \\ ${ }^{4}$ Graduação em Biociências Aplicadas à Farmácia, Departamento de Ciências Morfológicas, Universidade \\ Estadual de Maringá/UEM, Avenida Colombo, 5790, Zona 07, 08020-900 Maringá, PR, Brazil \\ ${ }^{5}$ Departamento de Histologia, Universidade Estadual de Londrina/UEL, Rodovia \\ Celso Garcia Cid, Km 380, 86051-970 Sabará, PR, Brazil \\ ${ }^{6}$ Departamento de Ciências Patológicas, Universidade Estadual de Londrina/UEL, \\ Rodovia Celso Garcia Cid, Km 380, 86051-970 Sabará, PR, Brazil
}

Manuscript received on April 23, 2018; accepted for publication on August 6, 2018

\begin{abstract}
How to cite: SOUZA ND, BELIN BS, MASSOCATTO CL, ARAÚJO SM, SANT’ANA DMG, ARAÚJO EJDA, FILHO PP, NIHEI OK AND MOREIRA NM. 2019. Effect of acetylsalicylic acid on total myenteric neurons in mice experimentally infected with Trypanosoma cruzi. An Acad Bras Cienc. 91: e20180389. DOI 10.1590/00013765201920180389 .
\end{abstract}

\begin{abstract}
We investigated the effects of acetylsalicylic acid (ASA) on the total myenteric neuronal population in the descending colon in Trypanosoma cruzi-infected mice. Thirty-five male Swiss mice, 60 days old, were divided into a control group (C group), control group treated with ASA (CA group), infected group (I group), and infected group treated with ASA (IA group). A total of 1300 trypomastigotes of the Y strain of T. cruzi were intraperitoneally inoculated in the IA and I groups. The CA and IA groups were treated with ASA intraperitoneally. At 75 days post-infection (dpi), all of the animals were sacrificed. Neurons in the colon were stained with Giemsa, quantified, and measured. No difference in the course of infection was observed between the IA and I groups, reflected by the parasitemia curve. Acetylsalicylic acid treatment in the CA and IA groups did not alter the total number of myenteric neurons compared with the $\mathrm{C}$ and I groups. The CA and IA groups exhibited an increase in the nuclear area, cytoplasmic area, and neuronal body area compared with the $\mathrm{C}$ and I groups. Future studies should elucidate the mechanism of action of ASA against Chagas' disease in the chronic phase.
\end{abstract}

Key words: acetylsalicylic acid, colon, Giemsa, mice, myenteric neurons, Trypanosoma cruzi.

Correspondence to: Neide Martins Moreira

E-mail: neidemartinsenf@yahoo.com.br

ORCid: https://orcid.org/0000-0002-5051-9295 


\section{INTRODUCTION}

Chagas' disease is caused by Trypanosoma cruzi, affecting approximately 8 million people worldwide and causing more than 10,000 deaths per year (World Health Organization 2018). In Brazil, chronic cases of Chagas' disease currently predominate because of vectorial transmission that has occurred in approximately 3 millions infected individuals (Portal da Saúde 2018a). Currently, the Amazon has seen an increase in acute cases of the disease, mainly caused by oral transmission (Portal da Saúde 2018b).

The disease has two phases: acute and chronic. The acute phase occurs from 30 to 90 days, with nonspecific symptoms and high blood parasitemia. Already in the chronicle, $70 \%$ of individuals do not present symptoms, with a significant reduction of circulating parasites in blood and the presence of specific antibodies. Only 30\% of patients develop symptoms of the chronic phase, which takes 10-30 years to develop cardiac and/or digestive symptoms (Rassi et al. 2012). In digestive forms, the disease can cause megaesophagus and megacolon, which are characterized by the dilation of hollow viscera, mainly reaching the sigmoid colon and rectum. Impairments of these functions promote changes in secretion, motility, and absorption and destruction of the myenteric plexus (Andrade et al. 2011).

According to Furness (2012), enteric nervous system (ENS) neurons are classified into motor neurons, interneurons, and sensory neurons. Motor neurons can be divided into two groups: excitatory and inhibitory. Both neuronal groups innervate the muscular tunica and muscular mucosa of the digestive tube and are mainly responsible for the induction of muscle contractions and relaxation of the esophagus and colon. The absence of motor coordination, muscle hypertrophy, and dysfunction of the esophagus and colon are all related to the destruction of ENS neurons, which occurs slowly and progressively (Jabari et al. 2011, Pallisera et al. 2011).
No treatment that is effective for the two phases of Chagas' disease is currently available. The drug that is mainly used in Brazil is benzonidazole, which was introduced in the 1970s to treat the acute phase of the disease and is beneficial for up to $70 \%$ of patients. However, benzonidazole has minimal effectiveness in the chronic phase, with a cure rate of only 10\% (Urbina 2010). Aside from limited efficacy, benzonidazole also causes unwanted side effects, often leading to the discontinuation of the treatment (Antinori et al. 2015).

Acetylsalicylic acid (ASA) has been widely used for the treatment of acute and chronic inflammatory diseases, with the aim of controlling the inflammatory process (Massocatto et al. 2017, Tatakihara et al. 2008). It is also indicated for the control of pain and fever. Therefore, in view of the formation of an inflammatory process during the chronic phase of Chagas' disease (Moreira et al. 2013), ASA may be promising as an alternative treatment for the chronic phase of this disease in the control of the inflammatory process.

Studies have shown that ASA reduces plasma levels of nitric oxide (NO) in infected mice and in supernatants of cultures of peritoneal macrophages that are activated with lipopolysaccharide (Tatakihara et al. 2008). Such an enzyme is considered antiparasitic because it has able to prevent the replication of $T$. cruzi (Lana and Tafuri 2011), further suggesting that ASA may be used to treat the chronic phase of Chagas' disease.

The present study investigated the effects of ASA on the number and morphometry of the total myenteric neuronal population in the descending colon in mice that were experimentally infected by T. cruzi.

\section{MATERIALS AND METHODS}

\section{ETHICAL ASPECTS}

The procedures were approved by the Ethical Conduct Committee on the Use of Animals in 
Experimentation (ECAE), State University of Maringá (opinion no. 057/2013) and Ethics Committee onAnimalUse (ECAU), StateUniversity of Londrina (opinion no. 156/2012). The present work was also approved by the Ethics Committee in Research - ECR of the State University of the West of Paraná - UNIOESTE (Opinion, the project was withdrawn from the evaluation process due to the fact that the experiment was carried out in another institution. Thus, it is not the responsibility of this committee to make the evaluation).

\section{ANIMALS}

Thirty male Swiss mice (Mus musculus), 60 days old, were obtained from the animal house of the State University of Londrina. The mice were randomly divided into four groups: uninfected control group treated with phosphate-buffered saline (PBS) only (C group; $n=5$ ), uninfected control group treated with AAS (CA group; $n=10$ ), infected group treated with PBS only (I group; $n=10$ ), and infected group treated with ASA (IA group; $n=10$ ).

The animals were kept in polypropylene cages $(414 \mathrm{~mm} \times 344 \mathrm{~mm} \times 168 \mathrm{~mm})$ that were lined with wood bedding. The cages were cleaned twice per week and had a galvanized grid top with a central depression for the deposition of food (Nuvilab Cr-1, Nuvital) and a water bottle (chlorinated). The animals received ad libitum access to food and water. They were housed under a constant temperature $\left(21-23^{\circ} \mathrm{C}\right)$ and alternating $12 \mathrm{~h} / 12 \mathrm{~h}$ light/dark cycle.

\section{INFECTION AND INDUCTION OF THE CHRONIC PHASE}

The animals in the I and IA groups were individually inoculated with 1300 bloodstream forms of the Y strain of T. cruzi intraperitoneally (i.p.). For induction of the chronic phase, six doses of benzonidazole (Lafepe, PE, Brazil; $100 \mathrm{mg} / \mathrm{kg}$ ) were administered by oral gavage $11,13,15,25$, 29 , and 48 days after inoculation.

\section{TREATMENT WITH ACETYLSALICYLIC ACID}

The amount of ASA (catalog no. A2093, SigmaAldrich; St. Louis, MO, USA) that was required to prepare a solution that contained $20 \mathrm{mg} / \mathrm{kg}$ of the active ingredient was calculated according to the animals' weight. Acetylsalicylic acid was prepared daily and dissolved in $100 \mu 1$ of dimethylsulfoxide in an eppendorf with the aid of a vortex. Phosphatebuffered saline ( $900 \mu \mathrm{l}, \mathrm{pH} 7.4)$ was added and the vortex was again used to complete solubilization (Massocatto et al. 2017, Oda et al. 2017).

Treatment with ASA was performed on consecutive days (55-63 days post-infection [dpi]) alternate and on days 65, 67, 69, 71, 73, and 75 dpi. Each animal in the CA and IA groups received 100 $\mu 1$ of $50 \mathrm{mg} / \mathrm{kg}$ ASA stock solution, i.p., at 8:00 AM. Animals in the $\mathrm{C}$ and I groups received 100 $\mu 1$ of 0.01 M PBS (pH 7.4), i.p. (Massocatto et al. 2017, Oda et al. 2017).

\section{EVOLUTION OF INFECTION}

Parasitemia was evaluated according to Brener (1962). A $5 \mu$ l blood sample was collected from the tail vein of each infected mouse, placed on a slide, and coverslipped $(22 \mathrm{~mm} \times 22 \mathrm{~mm})$. A total of 50 microscope fields were then analyzed daily from 4 to $15 \mathrm{dpi}$ and on alternate days from 15 to $20 \mathrm{dpi}$. The parasitemia curve was drawn using the mean parasite count of the inoculated animals in the I and IA groups, showing the following features: prepatent period (mean time between the day of experimental inoculation and the day at which the blood sample was positive for parasites), patent period (mean number of days where blood sample showed parasitemia), parasite peak (day with the highest number of parasites observed), and total parasitemia (mean of the sum of the number of parasites of each animal). 


\section{EUTHANASIA AND COLLECTION OF THE COLON}

At $81 \mathrm{dpi}$, all of the animals in the C, I, CA, and IA groups were euthanized by deep anesthesia with halothane gas (Tanohalo ${ }^{\circledR}$ ), which corresponded to 141 days of age for all of the mice. After thoracotomy and vertical laparotomy, the colons were removed and washed with $0.85 \%$ saline solution and filled with and immersed in acetic formaldehyde fixative solution. After $48 \mathrm{~h}$, they were microdissected under a stereomicroscope with transillumination to obtain total preparations of the muscular tunica and serous tunica. They were then stained using the Giemsa technique (Barbosa 1978) to reveal the total myenteric neuronal population, which was quantified and measured. The area of the colon (expressed in $\mathrm{cm}^{2}$ ) was calculated from the width and length of each organ. The animals were kept at the State University of Maringá until the moment of death.

\section{HISTOLOGICAL TECHNIQUE FOR INTRAMURALS NERVOUS GANGLIA IN PREPARATIONS THICKNESSES}

The Giemsa technique validated by Barbosa (1978), consists initially of the preparation of a Sorensen phosphate buffer with $\mathrm{pH}$ between 6.97 - 7.00. For this purpose, two solutions labeled here as A and B were prepared using the following protocol: 9.078 $\mathrm{g}$ of $\mathrm{KH}_{2} \mathrm{PO}_{4}$ (Potassium Phosphate Monobasic, Anhydro P.A, Synth; SP, Brazil) were added at $1000 \mathrm{ml}$ of Distilled Water to the solution (A), while to solution (B), $9.465 \mathrm{~g} \mathrm{NAH}_{2} \mathrm{PO}_{4} \cdot 7 \mathrm{H}_{2} \mathrm{O}$ (Dibasic Sodium Phosphate, Anhydrous A.A.S; Synth, SP, Brazil) were added at $1000 \mathrm{ml}$ of $\mathrm{H}_{2} \mathrm{O}$. Subsequently, $4 \mathrm{ml}$ of solution $\mathrm{A}$ and $6 \mathrm{ml}$ of solution B were added at $90 \mathrm{ml}$ of $\mathrm{H}_{2} \mathrm{O}$ while the $\mathrm{pH}$ of the solution was controlled. Posteriorly, 150 drops of ready for use Giemsa dye, were added and the microdissected intestinal segments were immersed in the dye solution for 24 hours. Then, the intestinal segments were dehydrated in graded concentrations of alcohols $(70 \%, 80 \%, 90 \%$ and $100 \%$ ) and diaphanized in Xylene solution (Sigma, Joinville, SC, Brazil). Finally, the intestinal segments were set between a slide and coverslip using one drop of resin Permount ${ }^{\circledR}$ Mount Medium (Sigma-Aldrich; SP, Brazil).

The myenteric neurons marking occurred because methylene blue (Giemsa dye) has affinity for ribosomes and, since all neurons have this organelle (Junqueira and Carneiro 2012) the methylene blue marked the total myenteric neuronal population (Barbosa 1978).

QUANTITATIVE AND MORPHOMETRIC ANALYSES OF TOTAL MYENTERIC NEURONAL POPULATION

A photonic microscope (Olympus CBA) with a $40 \times$ objective was used to quantify the neurons that were present in 120 microscopic fields throughout the distal colon. The areas $\left(\mu \mathrm{m}^{2}\right)$ of the cell body and nucleus of 300 neurons of the myenteric plexus of the distal colon were measured by capturing images with a MOTICAM 2000 digital camera coupled to a MOTIC B5 light microscope and ImagePro Plus software (Media Cybernetics).

\section{STATISTICAL ANALYSIS}

The statistical calculations were performed using BioEstat 5.0 software. The data distribution was evaluated using the D'Agostino Pearson test. Data with an unspecified distribution are expressed as medians and 25th and 75th percentiles and were compared using the Mann-Whitney test. The level of significance was $5 \%$. All of the statistical analyses were performed at the State University of West Paraná (UNIOESTE).

\section{RESULTS}

\section{EVOLUTION OF INFECTION}

The parasitemia curve presented a characteristic profile of the Y strain of T. cruzi in the two infected groups (I and IA groups), with a parasite peak on 
days 8 and 12 (Fig. 1). No significant difference was found between groups in infectivity, the prepatent period, the patent period, parasite peak, or total parasitemia ( $p>0.05$; Table I). No significant changes in the length, diameter, or total area of the colon were found in the mice at 75 dpi $(p>0.05$; Table II).

\section{QUANTITATIVE AND MORPHOMETRIC ANALYSIS} OF TOTAL MYENTERIC NEURONAL POPULATION

Treatment with ASA did not cause changes in the number of neurons in the total myenteric neuronal population between the uninfected groups (CA and
C groups; $p<0.05$ ) or between the infected groups (IA and I groups; $p>0.05$; Table III and Fig. 2). However, the results indicated that ASA promoted a tendency toward a reduction of the number of the total myenteric neuronal population in these animals (7.3\% reduction in CA group compared with the $\mathrm{C}$ group; $16.3 \%$ reduction in the IA group compared with the I group; $p>0.05$; Table III and Fig. 2).

Infection reduced the number of neurons of the total myenteric neuronal population $(18.0 \%$ reduction in the I group compared with the $\mathrm{C}$ group, $p<0.05 ; 24.0 \%$ reduction in the IA group compared with the CA group; $p<0.05$; Table III and Fig. 2).

\section{TABLE I}

Parasitological parameters in male Swiss mice, 60 days of age, that were infected with 1300 trypomastigotes of the $Y$ strain of T. cruzi and treated with PBS only (I) or infected and treated with ASA after 20 dpi (IA).

\begin{tabular}{ccccccc}
\hline Group & $\begin{array}{c}\text { Infectivity } \\
(\%)\end{array}$ & $\begin{array}{c}\text { Prepatent } \\
\text { period } \\
(\text { days })\end{array}$ & $\begin{array}{c}\text { Patent } \\
\text { period } \\
(\text { days })\end{array}$ & $\begin{array}{c}\text { Parasite peak } \\
\text { (trypomastigotes/ } \\
\left.\mathbf{m l} \times \mathbf{1 0}^{-3}\right)\end{array}$ & $\begin{array}{c}\text { Tenth day/ } \\
\text { infection } \\
(\text { trypomastigotes/ } \\
\left.\mathbf{m l} \times \mathbf{1 0}^{-3}\right)\end{array}$ & $\begin{array}{c}\text { Total parasitemia } \\
(\text { trypomastigotes/ml }\end{array}$ \\
\hline I $(n=10)$ & 100 & $3.1 \pm 0.6$ & $5.3 \pm 1.3$ & $3157.0 \pm 3053.1$ & $882.0 \pm 518.8$ & $7679.0 \pm 4923.5$ \\
IA $(n=10)$ & 100 & $3.2 \pm 0.4$ & $5.0 \pm 0.7$ & $3486.0 \pm 3784.4$ & $917.0 \pm 755.0$ & $8372.0 \pm 8131.9$ \\
\hline
\end{tabular}

The data are expressed as mean \pm standard deviation. No significant difference was found between groups at the times evaluated $(p>0.05)$. Mann-Whitney test.

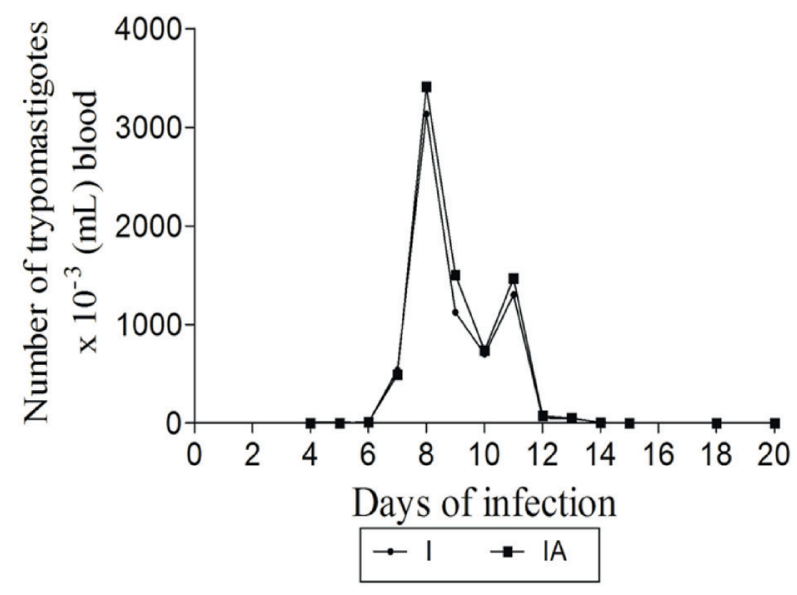

Figure 1 - Mean parasitemia curve in male Swiss mice, 60 days of age, that were infected with 1300 trypomastigotes of the Y strain of T. cruzi and were treated with PBS only (I) or infected and treated with ASA after 20 dpi (IA). No significant difference was found between groups at the times evaluated. Mann-Whitney test.
TABLE II

Mean and standard deviation of the length, width, and area of the colon in male Swiss mice, 22 weeks of age. Uninfected control group treated with PBS only (C); uninfected control group treated with ASA (CA); infected group treated with PBS only (I); infected group treated with ASA (IA) after 20 dpi. The inoculum was 1300 trypomastigotes of the Y strain of T. cruzi. Duration of infection: 81 days.

\begin{tabular}{cccc}
\hline \multicolumn{3}{c}{ Colon } \\
\hline Group & Length $(\mathbf{c m})$ & Width $(\mathbf{c m})$ & Area $\left(\mathbf{c m}^{2}\right)$ \\
\hline C $(n=5)$ & $8.8 \pm 0.5$ & $0.5 \pm 0.0$ & $4.6 \pm 0.3$ \\
CA $(n=4)$ & $9.2 \pm 1.0$ & $0.6 \pm 0.1$ & $5.2 \pm 0.7$ \\
I $(n=3)$ & $8.0 \pm 0.4$ & $0.6 \pm 0.1$ & $4.8 \pm 0.6$ \\
IA $(n=4)$ & $8.1 \pm 0.6$ & $0.5 \pm 0.1$ & $4.4 \pm 0.9$ \\
\hline
\end{tabular}

The data are expressed as mean \pm standard deviation. No significant difference was found between groups at the times evaluated. Mann-Whitney test. 

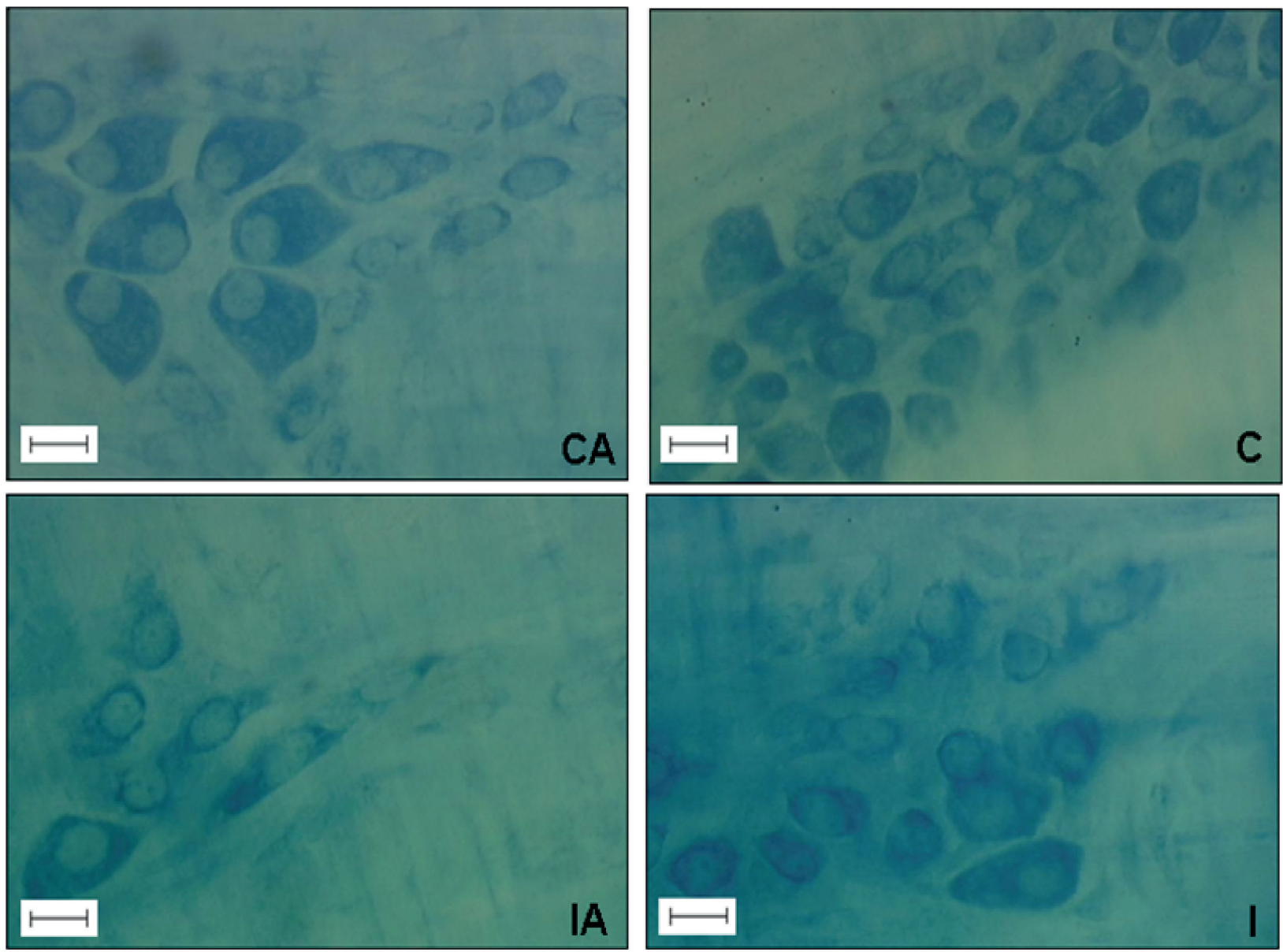

Figure 2 - Photomicrograph that shows quantitative and morphometric parameters of total myenteric neuron ganglia in the colon stained with the Giemsa technique in 141-day-old male Swiss mice. Uninfected control group treated with PBS only (C); uninfected control group treated with ASA (CA); infected group treated with PBS only (I); infected group treated with ASA (IA). A photonic microscope (MOTIC B5) with a 400x objective was used (bar $=50 \mu \mathrm{m})$.

Treatment with ASA in the uninfected animals (CA group) increased the nuclear area by $26.0 \%$, increased the cytoplasmic area by $75.0 \%$, and consequently increased the neuronal body area by $58.1 \%$ compared with the $\mathrm{C}$ group $(p<0.05)$. Treatment with ASA in the infected animals (IA group) increased the nuclear area by $22.4 \%$, increased the cytoplasmic area by $51.0 \%$, and consequently increased the neuronal body area by $39.4 \%$ compared with the I group ( $p<0.05$; Table III and Fig. 2).

Regarding the effect of the benzonidazole treatment on the animals of groups I and IA, considering that both groups received the same dosage of the drug (100 mg/kg/weight) and that group IA presented an increased of the area of the neuronal body of $39.4 \%$ over group I, it is believed that benzonidazole did not cause morphometric changes and that the observed increase (IA) is a result of the ASA treatment (Table III and Fig. 2).

Infection in the I group promoted atrophy of $14.1 \%$ of the nuclear area, $14.0 \%$ of the cytoplasmic area, and consequently $13.5 \%$ of the neuronal body area compared with the $\mathrm{C}$ group $(p<0.05)$. In the IA group presented atrophy of $16.4 \%$ of the nuclear area, $26.0 \%$ of the cytoplasmic area, and $24.0 \%$ of the neuronal body area compared with the CA group ( $p<0.05$; Table III and Fig. 2). 
TABLE III

Total myenteric neuron density and morphometric parameters of the colon in 141-day-old male Swiss mice. Uninfected control group treated with PBS only (C); uninfected control group treated with ASA (CA); infected group treated with PBS only (I); infected group treated with ASA (IA).

\begin{tabular}{ccccc}
\hline Parameter & \multicolumn{4}{c}{ Group } \\
\cline { 2 - 5 } & $\mathbf{C}(\boldsymbol{n}=\mathbf{5})$ & CA $(\boldsymbol{n}=\mathbf{4})$ & I $(\boldsymbol{n}=\mathbf{3})$ & IA $(\boldsymbol{n}=\mathbf{4})$ \\
\hline $\begin{array}{c}\text { Number of neurons in } 17.0 \\
\mathrm{~mm}^{2} \dagger\end{array}$ & $5819.20 \pm 754.80^{\mathrm{a}}$ & $5415.75 \pm 259.34^{\mathrm{a}}$ & $4769.00 \pm 65.00^{\mathrm{b}}$ & $3987.25 \pm 529.41^{\mathrm{b}}$ \\
Nuclear area $\left(\mu \mathrm{m}^{2}\right) \dagger$ & $54.5^{\mathrm{a}}(40.3 ; 68.6)$ & $68.6^{\mathrm{b}}(52.3 ; 87.4)$ & $46.8^{\mathrm{c}}(35.4 ; 61.0)$ & $57.3^{\mathrm{d}}(43.2 ; 77.6)$ \\
Cytoplasmic area $\left(\mu \mathrm{m}^{2}\right) \dagger$ & $75.4^{\mathrm{a}}(50.3 ; 111.6)$ & $132.0^{\mathrm{b}}(91.3 ; 227.7)$ & $65.0^{\mathrm{c}}(43.2 ; 97.8)$ & $98.2^{\mathrm{d}}(65.5 ; 153.2)$ \\
Cell body area $\left(\mu \mathrm{m}^{2}\right) \dagger$ & $132.6^{\mathrm{a}}(96.3 ; 182.7)$ & $209.7^{\mathrm{b}}(163.7 ; 311.3)$ & $114.6^{\mathrm{c}}(82.0 ; 156.5)$ & $159.8^{\mathrm{d}}(119.0 ; 227.2)$ \\
\hline
\end{tabular}

$\dagger$ Sum of total neurons quantified in 120 microscopic fields. $t$ Data are expressed as median percentiles (25th; 75th). Data followed by different letters (a, b, c and d) on the same line are significantly different $(p<0.05$; Mann-Whitney test).

\section{DISCUSSION}

The present study evaluated the effects of ASA on the number and morphometry of the total myenteric neuronal population in the distal colon in mice that were chronically infected with T. cruzi. The parasitemia curve was assessed from 4 to 22 dpi, and ASA was administered in the IA group only from $55 \mathrm{dpi}$. No changes in the evolution of infection were observed between the I and IA groups. The purpose of administering ASA only after this period was because the vast majority of human chagasic patients are in the chronic phase of T. cruzi infection (Portal da Saúde 2018a), indicating the need to investigate treatments for the chronic phase of Chagas' disease. There is no effective drug to treat patients with this disease. Benzonidazole is used for the treatment of Chagas' disease, but it presents only a $10 \%$ cure rate during the chronic phase (Lana and Tafuri 2011), and it has side effects that cause patients to discontinue treatment (Antinori et al. 2015).

Acetylsalicylic acid has been widely used for the treatment of acute and chronic inflammatory diseases (Silva et al. 2014). Chagas' disease is the result of a generalized inflammatory process (Moreira et al. 2013), and ASA may be used during the chronic phase of the disease to control the inflammatory process.
Patients with Chagas' disease are considered "lost" in the Brazilian healthcare system (Health Unic System) without a directed path of medical attention (Juberg 2009). A substantial aspect of Chagas' disease is intestinal constipation that is caused by chagasic colopathy (Júnior et al. 2013). Therefore, studies of the actions of ASA on the total myenteric neuron population are important.

Treatment with ASA did not alter the number of neurons of the total myenteric neuronal population in the CA group compared with the $\mathrm{C}$ group or in the IA group compared with the I group (Table III). These results suggest that this drug may be used to treat the chronic phase of Chagas' disease.

Acetylsalicylic acid can inhibit the synthesis of nitric oxide, consequently increasing the number of nests of amastigotes and inflammatory foci in parasitized tissue. Moreira et al. (2013) investigated the intestinal muscular tunica in mice that were infected with 1300 trypomastigotes of $T$. cruzi and reported the significant presence of inflammatory foci compared with uninfected animals.

Studies of human patients with chronic Chagas' disease have found evidence of inflammatory foci in the intestinal muscular layer, the presence of cells with cytotoxic potential, with the capacity to release toxic substances that can lead to the destruction of cells in this region, indicating the 
participation of an inflammatory process and neuronal denervation that are induced by $T$. cruzi infection (Silveira 2007).

In the present study, infection reduced the number of neurons of the total myenteric neuronal population $(18.0 \%$ reduction in the I group compared with the $\mathrm{C}$ group, $p<0.05 ; 24.0 \%$ reduction in the IA group compared with the CA, $p<0.05$; Table III).

T. cruzi infection decreased the number of myenteric neurons in the I group compared with the $\mathrm{C}$ group $(p<0.05)$ and in the IA group compared with the CA group ( $p<0.05$; Table III). These findings reinforce the literature that shows which $T$. cruzi infection causes death of the total myenteric neuronal population. Moreira et al. (2011) investigated quantitative and morphometric changes in myenteric neurons in the colon in mice that were experimentally infected with the Y strain of T. cruzi. Moreira et al. (2013) subsequently evaluated the effects of moderate physical exercise on parasitemia and the total myenteric neuronal population in the colon in mice that were inoculated with 1300 blood trypomastigotes of the Y strain of T. cruzi. Both of these studies reported results that were similar to the present study.

With regard to morphometry, the data showed alterations of the size of myenteric neurons. This neuronal hypertrophy in the CA group compared with the $\mathrm{C}$ group $(p<0.05)$ and in the IA group compared with the I group $(p<0.05)$ may indicate that ASA promotes increase the function of myenteric neuron machinery (Table III), suggesting that it increases gene expression and consequently the production of proteins that are involved in contractions and intestinal muscular dilation, thus improving peristalsis. Moreira et al. (2013) also found neuronal hypertrophy in trained and infected animals and trained and uninfected animals.

However, the results of observed hypertrophy indicate the necessity of future investigations aim to discover of investigating if the neuronal morphometric alterations provide benefits or harms to the host.

Regarding the treatment with benzonidazole in the animals of groups I and IA, the procedure proposed by Moreira et al. (2011) was adopted. In the present study, both groups of animals were treated with the same doses of benzonidazole, indicating that the increase in the area of the neuronal body observed in the animals of group IA in relation to group I resulted from treatment with ASA.

According to Schäfer et al. (2009), myenteric neurons maintain the capacity to adapt to microenvironmental influences, including inflammatory bowel disease and changes in eating habits. Thus, neuronal hypertrophy in the present study may reflect an attempt to overcome the lack of neurons that died while maintaining the homeostasis of intestinal transit in animals that were infected or not with T. cruzi.

Chagas' disease is characterized by a generalized inflammatory process (Moreira et al. 2013). Intestinal motility disorders are usually associated with constipation and dilation of the viscera. Treatment with ASA may be advisable for the maintenance of intestinal function in patients with chronic Chagas' disease.

The present study also found that infection promoted the atrophy of neurons of the total myenteric neuronal population in the I group compared with the $\mathrm{C}$ group $(p<0.05)$ and in the IA group compared with the CA group $(p<0.05)$. However, these results are different from Moreira et al. (2011, 2013), who observed neuronal hypertrophy of the total myenteric neuronal population. These discrepant findings indicate the necessity for further research.

In conclusion, ASA treatment under the present experimental conditions did not destroy myenteric neurons and increased the size of myenteric neurons. Overall, these findings leave a gap with regard to indicating the use of ASA for 
treatment of the chronic phase of Chagas' disease. Infection reduced the number of neurons of the total myenteric neuronal population and caused atrophy of the area of myenteric neurons, which contradicts the results of previous studies and indicates the need for further studies.

\section{ACKNOWLEDGMENTS}

The authors would like to thank the Fundação Araucaria for financial support.

\section{AUTHOR CONTRIBUTIONS}

De Souza ND, Belin BS, Massocatto CL, Araújo SMA, Sant'Ana DMG, Araújo EJA, Pinge-Filho $\mathrm{P}$ and Moreira NM, participated in the preparation and development of the proposal. De Souza ND and Belin BS, participated in the organization of the results. Moreira NM and Nihei OK, participated in the statistical analyzes. De Souza ND, Belin BS, participated in the preparation of the manuscript. Massocatto CL, Araújo SMA, Sant'Ana DMG, Araújo EJA, Pinge-Filho P, Nihei OK and Moreira $\mathrm{NM}$, participated in the critical review and final approval of the article.

\section{REFERENCES}

ANDRADE JPETAL. 2011. I Latin American guidelines for the diagnosis and treatment of Chagas' cardiomyopathy. Arq Bras Cardiol 97(2 Suppl 3): 1-48.

ANTINORI S ET AL. 2015. High frequency of adverse reactions and discontinuation with benznidazole treatment for chronic Chagas disease in Milan, Italy. Clin Infect Dis 60: 1873-1875.

BARBOSA AJA. 1978. Técnica histoquímica para gânglios nervosos intramurais e preparados espessos. Rev Bras Pes Med Biol 11: 95-97.

BRENER Z. 1962. Therapeutic activity and criterion of cure on mice experimentally infected with Trypanosoma cruzi. Rev Inst Med Trop 4: 389-396.

FURNESS JB. 2012. The enteric nervous system and neurogastroenterology. Nat Rev Gastroenterol Hepatol 9: 286-294.

JABARI S, DA SILVEIRA AB, DE OLIVEIRA CE, NETO SG, QUINT K, NEUHUBER W AND BREHMER A.
2011. Partial, selective survival of nitrergic neurons in chagasic megacolon. Histochem Cell Biol 135: 47-57.

JUBERG C. 2009. Chagas: one hundred years later. Bull World Health Organ 87: 491-492.

JÚNIOR HM, MOREIRA JPT, ISAAC RR, ALMEIDA AC, MOREIRA H AND KLUG WA. 2013. Anatomical and physiological changes in pelvic diaphragm in patients with chagasic megacolon submitted to Duhamel surgery. J Coloproctol 2: 62-69.

JUNQUEIRA LC AND CARNEIRO J. 2012. Biologia celular e molecular. Guanabara Koogan: Rio de Janeiro, p. 376.

LANA M AND TAFURI WL. 2011. Trypanosoma cruzi e doença de Chagas. In: Neves DP, de Melo AL, Linardi PM and Vitor RWA (Eds), Parasitologia Humana, 12th ed., Atheneu: São Paulo, p. 89-114.

MASSOCATTO CL, MOREIRA NM, MUNIZ E, ARAÚJO SM, PINGE-FILHO P, ROSSI RM, ARAÚJO EJA AND SANT'ANA DMG. 2017. Treatment with low doses of aspirin during chronic phase of experimental Chagas' disease increases oesophageal nitrergic neuronal subpopulation in mice. Int J Exp Pathol 98: 356-362.

MOREIRANM, SANT'ANADMG, ARAÚJO EJA, TOLEDO MJO, GOMES ML AND ARAÚJO SM. 2011. Neuronal changes caused by Trypanosoma cruzi: an experimental model. An Acad Bras Cienc 83: 545-555.

MOREIRA NM, SANTOS FN, TOLEDO MJO, MORAES SMF, ARAÚJO EJA, SANT'ANA DMG AND ARAUJO SM. 2013. Moderate physical exercise reduces parasitaemia and protects colonic myenteric neurons in mice infected with Trypanosoma cruzi. Int J Exp Pathol 94: 426-435.

ODA JY ET AL. 2017. Myenteric neuroprotective role of aspirin in acute and chronic experimental infections with Trypanosoma cruzi. Neurogastroenterol Motil 29: 1-13.

PALLISERA A, ORTIZ-DE-ZÁRATE L, MORAL A, REY F, LÓPEZ S, LÓPEZ MC, RIBAS R, FARRERAS N AND JORBA R. 2011. Chagas disease in the differential diagnosis of megacolon. Rev Esp Enferm Dig 103: 554555.

PORTAL DA SAÚDE. 2018a. Disponível em: http:// portalsaude.saude.gov.br/index.php/o-ministerio/ principal/secretarias/svs/doenca-de-chagas. Acessado em: 08-04-2018.

PORTAL DA SAÚDE. 2018b. A doença de Chagas. Disponível em: http://u.saude.gov.br/index.php/ pqavs/644-o-ministerio/o-ministerio-principal/secretariasvs/vigilancia-de-a-a-z/doenca-de-chagas. Acessado em: 17-04-2018.

RASSI A JR, RASSI A AND MARCONDES DE REZENDE J. 2012. American trypanosomiasis (Chagas disease). Infect Dis Clin North Am 26: 275-291.

SCHÄFER KH, VAN GINNEKEN C AND COPRAY S. 2009. Plasticity and neural stem cells in the enteric nervous system. Anat Rec 292: 1940-1952. 
SILVA JM, MENDONÇA PM AND PARTATA AK. 2014. Anti-inflamatórios não-esteróides e suas propriedades gerais. Rev Científica ITPAC 7: 1-15.

SILVEIRA ABM. 2007. Estudo estrutural dos componentes do sistema nervoso entérico e de células inflamatórias: uma contribuição à imunopatologia do megacólon chagásico (Doctoral thesis). Belo Horizonte: Universidade Federal de Minas Gerais.

TATAKIHARA VLH, CECCHINI R, BORGES CL, MALVEZI AD, GRAÇA-DE-SOUZA VK, YAMADAOGATTA SF, RIZZO LV AND PINGE-FILHO P. 2008.
Effects of cyclooxygenase inhibitors on parasite burden, anemia and oxidative stress in murine Trypanosoma cruzi infection. FEMS Immunol Med Microbiol 52: 47-58.

URBINA JA. 2010. Specific chemotherapy of Chagas disease: relevance, current limitations and new approaches. Acta Trop 115: 55-68.

WORLD HEALTH ORGANIZATION. 2018. Chagas disease (American trypanosomiasis). Retrieved from: http://www. who.int/chagas/epidemiology/en/.Accessed April 17, 2018. 